\title{
AFLATOXIN REMOVAL OF PEANUT MEALS WITH AQUEOUS ETHANOL
}

\author{
II. FONSECA; M.A.B. REGITANO-d'ARCE \\ Dep. de Ciencia e Tecnologia Agroindustrial da ESALQ/USP - Caixa Postal 9, CEP: 13418-900-Piracicaba,SP.
}

\begin{abstract}
A preliminary approach to achieve compatible simultaneous extraction of aflatoxin and residual oil from pressed oil meals was conducted to determine the minimum amount of water to be added to ethanol versus necessary time to achieve complete removal of aflatoxin. Commercial anhydrous, 96,93 and $90^{\circ} \mathrm{GL}$ ethanol were utilized in trials with Soxhlet extractors. Commercial anhydrous ethanol did not remove aflatoxin completely and the extraction efficiency in minutes was directly proportional to the amount of water present in the ethanol, as expected. Although $96^{\circ} \mathrm{GL}$ ethanol was efficient, alcoholic strengths between 96 and $99^{\circ} \mathrm{GL}$ need be evaluated to improve oil extraction, provided they do not decrease aflatoxin removal efficiency.
\end{abstract}

Key Words: Aflatoxin, peanut meal, oil meals, removal, extraction, aqueous ethanol, ethanol.

\section{REMOÇÃo DE AFLATOXINA DE TORTAS DE AMENDOIM COM ETANOL AQUOSO}

RESUMO: Uma metodologia preliminar foi testada para a extraçāo simultânea de aflatoxina e de Gleo residuål de tortas oleaginosas. $O$ objetivo deste primeiro experimento foi conhecer a quantidade de água, a ser adicionada ao etanol, e o tempo, mínimos para a remoção da aflatoxina. Etanol anidro comercial e a 96,93 e $90^{\circ} \mathrm{GL}$ foram utilizados em extratores de Soxhlet. $O$ etanol anidro comercial não removeu completamente a aflatoxina, mesmo com 300 min de extraçūo. A $96^{\circ} \mathrm{GL}$ a remoçẫo foi completa aos 240 min; a $93^{\circ} \mathrm{GL}$ foi completa aos 210 min e a $90^{\circ} \mathrm{GL}$ foi completa aos $180 \mathrm{~min}$. A eficiência da extração aumentou proporcionalmente à quantidade de água no etanol. Embora o etanol a $96^{\circ} \mathrm{GL}$ tenha sido eficiente na remoção da aflatoxina, outras graduaçōes alcoblicas deverāo ser estudadas para melhorar a extração do óleo uma vez que esta é inversamente proporcional a quantidade de água no etanol.

Descritores: aflatoxina, tortas oleaginosas, torta de amendoim, remoçăo, extração, etanol, etanol aquoso.

\section{INTRODUCTION}

The removal or destruction of aflatoxin in oil meals has been tried in the last twenty five years, attempting to recover an excellent source of protein for use in animal feeding and even in human diet for low income populations.

Two procedures for the destruction of aflatoxin have attained some success in some parts of the world such as the utilization of hydrogen peroxide in India (SREENIVASAMURTHY et al., 1967) and the ammoniation process in the USA for cottonseed meals (GARDNER et al., 1971).

Several solvents and solvent mixtures have also proved to be efficient in removing aflatoxins from contaminated food materials, once aflatoxin is not extracted by hexane during oil extraction. Among them, aqueous ethanol (RAYNER et al., 1970) and ethanol/methanol, hexane/ethanol mixtures (VORSTER, 1966) have also been tried with success.
However, the use of those solvents has not been cited as a practice in industry yet, either because costs would probably raise prices or due to technical difficulties.

The advent, in 1975, of the PROALCOOL program in Brazil, by which the production of ethanol as fuel for use in motor cars has increased the number of distilleries, raised the production of cthanol to the figure of 12 billion litres per year, as we have today ca. 6 million cars running on hydrated alcohol.

The great availability of ethanol in contrast to hexane, which is imported by Brazil, has directed scientists and technicians to make studies to substitute ethanol for hexane in the extraction of oil from oilseeds and oil meals (REGITANO-d'ARCE; LIMA, 1987; REGITANOd'ARCE et al., 1991).

The change from hexane to ethanol would lead to some advantages, one of the most important being the possibility of removing aflatoxins from 
contaminated oil meals, especially peanut and cottonseed meals. As it is known, the increase of water in ethanol renders oil extraction difficult and favors aflatoxin removal.

Due to all those possibilities some technical studies have been made for the extraction of oil with ethanol as well as for the integration of alcohol distilleries/oil mills in the same site, with advantages to both, mainly because there is an increasing consortiation of peanut crop with sugar cane plantations.

\section{MATERIAL AND METHODS}

Homogenized peanut meal naturally contaminated with $400 \mu \mathrm{g} / \mathrm{kg}$ of aflatoxin $B_{1}$ was utilized throughout the test. The extraction was conducted in Soxhlet extractors during 90 to 300 minutes depending on the alcoholic strength of the mixture. Commercial anhydrous, 96,93 and $90^{\circ} \mathrm{GL}$ ethanol were used in the extractions, with five replicates. Aflatoxin was determined before and after the extractions according to LEE (1965). The water content of the meal determined by the oven method (BRASIL, 1976) at $105^{\circ} \mathrm{C}$ until constant weight showed an average of $8.0 \%$.

\section{RESULTS AND DISCUSSION}

The results obtained are in TABLES 1 to 4 and they represent the average of five replicates.

TABLE 1 shows that anhydrous ethanol did not extract aflatoxin significantly. The 50\% reduction in 180 min may be due to the moisture content of the peanut meal at the beginning, since further on, until $300 \mathrm{~min}$ no more aflatoxin was removed.

Ethanol $96^{\circ} \mathrm{GL}$ was more efficient (TABLE 2) since after $240 \mathrm{~min}$ of extraction, aflatoxin was not detected in the meal.

TABLE 1 - Influence of time on the final aflatoxin content of peanut meal extracted with anhydrous ethanol.

\begin{tabular}{lrrrr}
\hline \hline Time (min) & 120 & 180 & 240 & 300 \\
\cline { 2 - 5 } $\begin{array}{l}\text { Aflatoxin } \\
(\mu \mathrm{g} / \mathrm{kg})\end{array}$ & 400 & 200 & 200 & 200 \\
\hline \hline
\end{tabular}

Sci. agric., Piracicaba, 50(1):154-156, fev./maio, 1993
TABLE 2. Influence of time on the final aflatoxin content of peanut meal extracted with $96^{\circ} \mathrm{GL}$ ethanol.

\begin{tabular}{lrrrr}
\hline \hline Time (min) & 120 & 180 & 240 & 300 \\
\cline { 2 - 5 } $\begin{array}{l}\text { Aflatoxin } \\
(\mu \mathrm{g} / \mathrm{kg})\end{array}$ & 200 & 100 & ND & ND \\
\hline
\end{tabular}

Ethanol at 93 and $90^{\circ} \mathrm{GL}$ increased extraction efficiency (TABLES 3 and 4) decreasing the time needed to remove all aflatoxin.

TABLE 3 - Influence of time on the final aflatoxin content of peanut meal extracted with $93^{\circ} \mathrm{GL}$ ethanol.

\begin{tabular}{crrrrrr}
\hline $\begin{array}{c}\text { Time } \\
(\min )\end{array}$ & 90 & 120 & 150 & 180 & 210 & 240 \\
\cline { 2 - 7 } $\begin{array}{c}\text { Aflatoxin } \\
(\mu \mathrm{g} / \mathrm{kg})\end{array}$ & 266 & 114 & 60 & 43 & ND & ND \\
\hline
\end{tabular}

TABLE 4 - Influence of time on the final aflatoxin content of peanut meal extracted with $90^{\circ} \mathrm{GL}$ ethanol.

\begin{tabular}{lcccc}
\hline \hline Time (min) & 90 & 120 & 150 & 180 \\
\cline { 2 - 5 } $\begin{array}{l}\text { Aflatoxin } \\
\mu \mathrm{g} / \mathrm{kg})\end{array}$ & 100 & 50 & 40 & $\mathrm{ND}$ \\
\hline
\end{tabular}

It is clear that the use of $96^{\circ} \mathrm{GL}$ ethanol for $240 \mathrm{~min}$ was adequate for extraction of aflatoxin because 93 and $90^{\circ} \mathrm{GL}$ did not reduce extraction time significantly.

The amount of water in $96^{\circ} \mathrm{GL}$ ethanol will decrease the efficiency of oil extraction for the solubility of oil is lower in the presence of water. However, the relatively high boiling point of the mixture $\left(78.3^{\circ} \mathrm{C}\right)$ may overcome, at least partially, this problem.

Slightly higher alcoholic strengths, such as 97 and $98^{\circ} \mathrm{GL}$ may be tested to improve oil extraction. Additional studies must also be made to evaluate possible losses of nutrients. 


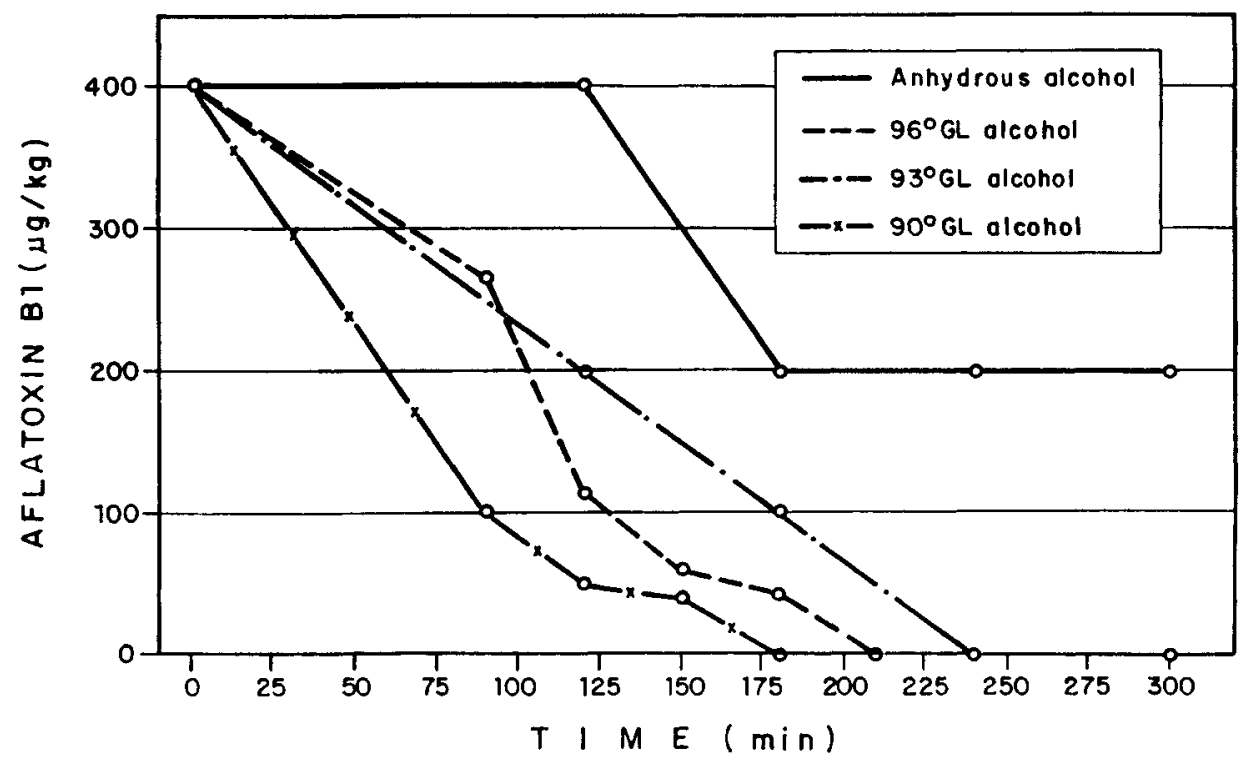

Fig. 1 - Aflatoxin removal from peanut meals: influence of alcoholic strength on extraction time.

\section{CONCI.USIONS}

- Commercial anhydrous ethanol is not suitable for removal of aflatoxin from oilseed meals.

- Ethanol at 96,93 and $90^{\circ} \mathrm{GL}$ are adequate for aflatoxin removal but the last two are not recommended for oil extraction.

- More studies must be carried out in order to optimize simultaneous aflatoxin and oil extraction.

\section{REFERENCES}

BRASIL. Ministério da Agricultura. Regras para análise de sementes. Brasília. Departamento de Produçāo Vegetal, DISEN. 1976. 188p.

GARDNER, H.K.; KOLTUN, S.P.; DOLLEAR, F.G.; RAYNER, E.T. Inactivation of aflatoxin in peanut and cottonseed meals by ammoniation. Journal of the American Oil Chemists'Society, Champaign, v.48, p.70, 1971 .

LEE, W.V. Quantitative determination of aflatoxin in groundnut products. Analyst, London, v.90, p.305307, 1965.

RAYNER, E.T.; DOLLEAR, F.G.; CODIFER Jr., L.P. Extraction of aflatoxins from cottonseed and peanut meals with ethanol. Journal of the American Oil Chemists'Society, Champaign, v.47, p.26, 1970.

REGITANO-d'ARCE, M.A.B.; LIMA, U.A. Emprego do álcool etílico na extração de óleo de sementes de girassol (Helıanthus annuus L.). Ciência e Tecnologia de Alimentos, Campinas, v.7, n.1, p.1-14, 1987.

REGITANO-d'ARCE, M.A.B.; LIMA, U.A.; GUNTHER, P.A.S. Kinetics of sunflower cake oil extration by ethanol. In: INTERNATIONAL MEETING ON FATS AND OILS TECHNOLOGY, SYMPOSIUM AND EXHIBITION, 1991, Campinas. Proceedings... Campinas : UNICAMP, 1991 . p.166169.

SREENIVASAMURTHY, V.; PARPIA, H.A.B.; SRIKANTA, S.; SHANKARMURTHY, A. Detoxification of aflatoxin in peanut meal by hydrogen peroxide. Journal of the Association of the Official Analytical Chemists, Arlington, v.50, p.350-354, 1967.

VORSTER, L.J. Studies on the detoxification of peanuts contaminated by aflatoxin. Revue Française du Corps Gras, Paris, v.13, p.7-12, 1966.

Trabalho entregue para publicação em 14.02 .92

Trabalho aprovado para publicação em 01.04 .92 